\title{
Suspicion of Frasier's syndrome in the nephrology unit of the Internal Medicine department of the HUEH: Case study and review of the literature.
}

Axler JEAN PAUL ( $\square$ jeanpaulaxler@hotmail.com )

Hospital of the State University of Haiti https://orcid.org/0000-0003-1490-605X

\section{Dieuguens LOUIS}

Hospital of the State University of Haiti

Ansly Jefferson DESRAVINES

Hospital of the State University of Haiti

Raema Mimrod JEAN

Hospital of the State University of Haiti

Alfadler JEAN BAPTISTE

Hospital of the State University of Haiti

Jean Henold BUTEAU

Hospital of the State University of Haiti

Wislet ANDRE

Hospital of the State University of Haiti

\section{Case Report}

Keywords: Frasier syndrome, End-stage renal failure, young, HUEH, Haiti

Posted Date: June 16th, 2021

DOl: https://doi.org/10.21203/rs.3.rs-622151/v1

License: (9) This work is licensed under a Creative Commons Attribution 4.0 International License.

Read Full License 


\section{Abstract}

Objective

Frasier syndrome is a rare genetic nephropathy characterized by the presence of progressive glomerulopathy with proteinuria associated with male pseudo hermaphroditism. This case study described a picture of a young boy where the clinical suspicion context reminded the Frasier Syndrome. To our knowledge, this case is the first described in Haiti.

Case study

This is a 19 years old young phenotypically male, born with a genital anomaly, was seen on referral at the nephrology/dialysis unit of the internal medicine department of HUEH for evaluation and follow-up. Insidious progression of symptoms had occurred over 3 years. Over three months of outpatient follow-up, he had four sets of renal labs drawn, and all showed impaired renal function. At the ultrasound a bilateral cryptorchidism is described in the inguinal, and presence of functional ovaries with follicles of variable size scattered in the parenchyma. So, in the light of these anamnestic, clinical and paraclinical findings we concluded to the diagnosis of end-stage renal failure by progressive glomerulopathy in a context of Frasier's syndrome.

Conclusion

With any clinical picture consisting of genital anomalies at birth, renal symptomatology during childhood and the diagnosis of renal failure during adolescence, rare genetic nephropathies, such as Frasier syndrome must be considered.

\section{Background}

Frasier syndrome is a rare genetic nephropathy caused by a point mutation in the WT 1 gene located on chromosome 11. (1-4) First described in 1964 by Professor Frasier (5), it is characterized by the presence of progressive glomerulopathy with proteinuria associated with male pseudo hermaphroditism (presence of female external genitalia in a male phenotype) $(2,3,6-8)$. Initial manifestations of patients with Frasier syndrome include morning edema (facial puffiness), elevated blood pressure, proteinuria, with hypospadias and/or ambiguity of the external genitalia accompanied by cryptorchidism at birth $(2,3,9)$. $(2,3,9)$ The symptomatology evolves into a treatment-resistant nephrotic syndrome that progressively leads to end-stage renal failure during the first two decades of the child's life. $(2,3,6,9-11)$ We present a case of Frasier syndrome that was seen at the nephrology/dialysis unit of HUEH.

\section{Case Study}

This is a young phenotypically male (presence of secondary male characteristics) who is 19 years old and born with a genital malformation in a family without history of consanguinity. They were seen on 
referral at the nephrology/dialysis unit of the internal medicine department of HUEH for evaluation and follow-up. Insidious progression of symptoms had occurred over 3 years. However, the patient developed new symptoms over the 21 days preceding this consultation at the hospital. The patient was experiencing morning puffiness of the face and postprandial vomiting. he had episodes of dyspnea with effort that evolved into dyspnea at rest, orthopnea requiring two pillows, and paroxysmal nocturnal dyspnea. $\mathrm{He}$ also developed ascending edema of the lower limbs with malleolar onset. At an outside hospital, urine examination showed proteinuria (+++), urinary tract infection with severe leukocyturia (30-35 white blood cells per field) and hematuria (6-8 red blood cells per field). He had a severe anemia $(7.8 \mathrm{~g} / \mathrm{dl})$, normocytic normochromic (MCV: 84.1; MCHC: 34.2), a predominantly neutrophilic hyperleukocytosis $(14,000 ; 86 \%)$, an altered ionogram with mild hyperkalemia $(5.71 \mathrm{mEq} / \mathrm{L})$ and an altered renal balance with creatininemia $(25.25 \mathrm{mg} / \mathrm{dl}) ; \mathrm{BUN}(90 \mathrm{mg} / \mathrm{dl})$. In the light of these assessments, he was referred to the emergency department and followed up with nephrology for appropriate care.

In the emergency room, he was noted to have a puffy face, pale palpebral conjunctiva, and crackling rales at the base of the left lung. His scrotum was empty to palpation and enlarged, though nontender. His external genitalia were characterized by a micropenis with the presence of a rough vaginal orifice attached to the perineum.

Over three months of outpatient follow-up, he had four sets of renal labs drawn, and all showed impaired renal function (Fig. 3). The last one revealed a creatinine level of $10.5 \mathrm{mg} / \mathrm{dl}$. The glomerular filtration rate was calculated: MDRD eGFR $=8.21 \mathrm{ml} / \mathrm{min} / 1.73$. His phosphocalcic assessment showed hypocalcemia at $8.1 \mathrm{mg} / \mathrm{dl}$ and a 24-hour proteinuria at $578 \mathrm{mg}$. During the same period, he had four altered blood counts showing severe anemia that did not correct (Fig. 3), and the last of these revealed a severe microcytic hypochromic anemia with a hemoglobin level of $7.4 \mathrm{gr} / \mathrm{dl}, \mathrm{MCV}$ at $79.2 \mathrm{fl}$. and a MCHC at 26.6 $\mathrm{pg}$, and hyperleukocytosis of 15800 with neutrophilic predominance (76\%). His hormonal tests showed a decrease in testosterone level to $242 \mathrm{ng} / \mathrm{dl}$, an increase in hydroxyprogesterone level to 67.9, and an increased LH level to $26 \mathrm{mlU} / \mathrm{ml}$.

He also had a pelvic ultrasound showing poor cortico-medullary differentiation with small kidneys (right kidney $9.7 * 5.02 \mathrm{~cm}$; left kidney $9.7 * 5.6 \mathrm{~cm}$ ) and dilatation of the pyelocaliceal system and proximal ureter. (Figure 1)

Bilateral cryptorchidism is also described in the inguinal region (right testicles $2.7 * 1.1 \mathrm{~cm}$ and left $1.37 * 1.04 \mathrm{~cm})$, and presence of functional ovaries $\left(1.6 * 1.1 \mathrm{~cm}\right.$ on the right and $1.5^{\star} 1.7 \mathrm{~cm}$ on the left) with follicles of variable size scattered in the parenchyma. (Fig. 2)

He also has a prostate gland $(4.83 \mathrm{~cm} 3)$. Doppler ultrasound of the kidneys described a significant alteration of the renal vascularization and an absence of opacification of the cortical arteries in the periphery. He had performed an echocardiogram concluding a dilated cardiomyopathy with mild alteration of the systolic ejection fraction (46.4\%) associated with a pericardial effusion without signs of tamponade. Chest radiography also described congestive cardiomegaly with signs of vessel cephalization and impaction of the left hilum. 
In the light of these anamnestic, clinical and paraclinical findings we concluded to the diagnosis of endstage renal failure by progressive glomerulopathy in a context of Frasier's syndrome complicated by a global cardiac decompensation class IV.

During his stay on the unit, he received 31 sessions of hemodialysis and 9-unit bags of compatible packed red blood cells that did little to correct his anemia (Fig. 3). He was managed for cardiac decompensation and was placed on furosemide, enalapril, carvedilol, iron, thiamine, erythropoietin and omeprazole. After 12 days he developed a compensated heart disease and his clinical condition improved, so he was discharged. He continued hemodialysis sessions in the unit and genetic tests were planned to investigate possible mutations that would be diagnostic of Frasier syndrome. However, he suddenly succumbed to cardiac arrest in post-dialysis.

\section{Discussion}

Mutations in the WT1 gene result in a spectrum of very rare congenital diseases characterized by abnormalities in gonadal and urinary tract development and are the cause of WAGR (Wilms-AniridiaGenitourinary-mental Retardation) syndromes, Denys-Drash syndrome and Frasier syndrome. $(3,7,12$, 13) Initial manifestations of patients with nephropathy due to the WT1 gene mutation include edema, proteinuria, pseudo hermaphroditism, hypospadias or cryptorchidism at birth. (9) Frasier syndrome and Denys-Drash syndrome (DDS) share common features and are both characterized by a steroid-resistant nephrotic syndrome, which leads to renal failure, gonadal tumor (most often gonadoblastoma or dysgerminoma), and male pseudo hermaphroditism. $(2,12,14)$ The main differences lie in the more prominent manifestation of renal symptomatology during childhood in DDS, contrasting FS which mostly manifests during the second decade, particularly during adolescence or young adulthood. $(3,7,9,12,15$, 16)Additionally, the risk of development Wilms' tumors is higher in DDS. $(3,6,7,12,13,16,17)$. In our case, we eliminated DDS because the renal failure occurs mainly in the second decade (16-19 years), as mentioned in the literature $(6,7,18,19)$

Frasier syndrome is defined by the presence of progressive glomerulopathy with proteinuria associated with male pseudo hermaphroditism (presence of female external genitalia in a male phenotype) $(2,3,6-$ 8). To our knowledge, this case is the first described in Haiti. Taking into account the appearance of the external genitalia, phenotype and sex chromosomes, Frasier syndrome is classified into 3 types (2):
a) Type 1: characterized by the presence of external female genitalia with sex chrom
most common
b) Type 2 by the presence of male external genitalia with sex chromosome $46, X Y$
c) Type 3 presence of external female genitalia with sex chromosome 46 , XX.

This case was closest to type 2 because of the male phenotype with predominant development of male sexual characteristics (no well-defined breasts or vagina). The mean age at diagnosis of Frasier 
syndrome was estimated to be $16.3 \pm 2.3$ years $(2,15,20)$, which is also the age at which the diagnosis of end-stage renal disease is often made, although the onset of renal symptoms of proteinuria, edema and hypertension typically begins between $2-10$ years of age. $(1,2,6,9,10,19,20)$ This patient had a similar picture; since his childhood he was often in hospital for reasons of facial oedema and alteration of the renal function. This prompted the abdominal ultrasound revealing a decrease in kidney size of kidneys, and allowed the diagnosis of preterminal renal insufficiency at age 16.

Two elements are essential to confirm the diagnosis of Frasier syndrome: renal biopsy and cytogenetic study that identifies the WT1 gene mutation located on chromosome 11p13. (7) Renal biopsy performed before the stage of end-stage failure describes segmental and focal glomerulosclerosis $(8,18,21)$ generally caused by the WT1 gene mutation leading to alterations in the podocytes with areas of proliferation $(8,9,15) .(8,9,15)$ It is due to point mutations in intron 9 of the WT1 gene, resulting in the loss of the lysine-threonine-serine (KTS) containing isoforms of the WT1 protein and result in deficiency of the usually more abundant KTS positive isoforms and reversal of the normal KTS positive/negative ratio from 2:1 to 1:2. (16). This has a great impact on tumor risk, because patients with Frasier syndrome have one normal copy of WT1 and one that can only produce the KTS negative isoform, this might explain why patients with Frasier syndrome do not develop Wilms's tumor which also explains the observed external genitalia changes, because the KTS positive isoform might participate in another pathway required for normal male urogenital development. $(2,16,19)$ There are extrarenal manifestations of the WT1 gene mutation such as the presence of cardiomyopathies (21), a finding that was identified in our patient at echocardiography showing dilated cardiomyopathy with slight alteration of the systolic ejection fraction $(46,4 \%)$. However, this could also be a complication of his chronic end-stage renal failure.

In our case, the renal biopsy was no longer appropriate since he had arrived at the nephrology unit very late and already had end-stage renal failure with hypotrophic kidneys. During his stay, we conducted genetic tests to confirm the presence of the mutations. Unfortunately, he died suddenly due to cardiac arrest after a dialysis session. As a result, the genetic tests were not performed to confirm mutations that would explain the clinical and paraclinical findings characteristic of Frasier syndrome.

\section{Conclusion}

With any clinical picture consisting of genital anomalies at birth, renal symptomatology (facial edema, proteinuria and high blood pressure) during childhood and the diagnosis of renal failure during adolescence, rare genetic nephropathies, such as Frasier syndrome and Dennis Drash syndrome, must be considered. $(7,20,23,24)$. In low-income settings such as ours, where genetic technology is not always available, the diagnosis of Frasier syndrome should be considered in any child with developmental abnormalities of the external genitalia presenting with isolated proteinuria and/or signs of impaired renal function during childhood or adolescence.

\section{Declarations}


Statement of ethics approval - This study has been approved for publication by the head directory of the Internal Medicine of the State University Hospital of Haiti as it's a teaching Hospitals.

Statement on participant consent - The patient's mother consented to participate and publish the relevant information about the case, and the information about the identity was kept confidential.

Acknowledge

Special thanks to Dr. Nelle-Ange Mele, Dr. Joseph Daniel Perez de Corcho, and Dr. Rolvix Patterson, for their invaluable help in translating the manuscript.

Funding

This research did not receive any specific grant from funding agencies in the public, commercial, or notfor-profit sectors.

Declaration of Competing Interest

No conflict of interest.

\section{References}

1. Yang Y, Zhao F, Tu X, Yu Z. Mutations in WT1 in boys with sporadic isolated steroid-resistant nephrotic syndrome. Genet Mol Res. 2016 Mar 11;15(1).

2. Ezaki J, Hashimoto K, Asano T, Kanda S, Akioka Y, Hattori M, et al. Gonadal tumor in Frasier syndrome: A review and classification. Cancer Prev Res. 2015 Apr 1;8(4):271-6.

3. Peco-Antić A, Ozaltin F, Parezanović V, Miloševski-Lomić G, Zdravković V. Proteinuria in Frasier syndrome. Srp Arh Celok Lek. 2013;141(9-10):685-8.

4. Hildebrandt F. Genetic kidney diseases. Lancet [Internet]. 2010;375(9722):1287-95. Available from: http://dx.doi.org/10.1016/S0140-6736(10)60236-X

5. Frasier SD, Bashore RA, Mosier HD. Gonadoblastoma associated with pure gonadal dysgenesis in monozygous twins. J Pediatr. 1964;64(5):740-5.

6. Jalanko H, Kääriäinen H. Nephrotic Disorders [Internet]. Sixth Edit. Emery and Rimoin's Principles and Practice of Medical Genetics. Elsevier; 2013. 1-13 p. Available from:

http://dx.doi.org/10.1016/B978-0-12-383834-6.00068-9

7. Miller-Hodges E. Clinical aspects of WT1 and the kidney. Methods Mol Biol. 2016;1467:15-21.

8. DEMMER L, PRIMACK W, LOIK V, BROWN R, THERVILLE N, MCELREAVEY K. Frasier Syndrome. J Am Soc Nephrol [Internet]. 1999 Oct 1 [cited 2021 May 8];10(10):2215-8. Available from: https://jasn.asnjournals.org/lookup/doi/10.1681/ASN.V10102215

9. Sun S, Xu L, Bi Y, Wang J, Zhang Z, Tang X, et al. Early diagnosis of WT1 nephropathy and follow up in a Chinese multicenter cohort. Eur J Med Genet. 2020 Nov 1;63(11). 
10. Ruf RG, Schultheiss M, Lichtenberger A, Karle SM. Prevalence of WT1 mutations in a large cohort of patients with steroid-resistant and steroid-sensitive nephrotic syndrome. Kidney Int [Internet]. 2004 [cited 2021 May 8];66:564-70. Available from: http://genome.ucsc.edu/

11. Melo KFS, Martin RM, Costa EMF, Carvalho FM, Jorge AA, Arnhold IJP, et al. An unusual phenotype of Frasier syndrome due to IVS $9+4 \mathrm{C}>\mathrm{T}$ mutation in the WT1 gene: predominantly male ambiguous genitalia and absence of gonadal dysgenesis. J Clin Endocrinol Metab [Internet]. 2002 Jun [cited 2021 May 8];87(6):2500-5. Available from: http://www.ncbi.nlm.nih.gov/pubmed/12050205

12. Liu EK, Suson KD. Syndromic Wilms tumor: a review of predisposing conditions, surveillance and treatment. Transl Androl Urol [Internet]. 2020 Oct 1 [cited 2021 Apr 16];9(5):2370-81. Available from: http://www.ncbi.nlm.nih.gov/pubmed/33209710

13. Yang YH, Zhao F, Feng DN, Wang JJ, Wang CF, Huang J, et al. Wilms' tumor suppressor gene mutations in girls with sporadic isolated steroid-resistant nephrotic syndrome. Genet Mol Res. 2013 Dec 4;12(4):6184-91.

14. Avni EF, Vandenhoute K, Devriendt A, Ismaili K, Hackx M, Janssen F, et al. Update on congenital nephrotic syndromes and the contribution of US. Vol. 41, Pediatric Radiology. 2011. p. 76-81.

15. Chiba $Y$, Inoue $C N$. Once-daily low-dose cyclosporine a treatment with angiotensin blockade for longterm remission of nephropathy in frasier syndrome. Tohoku J Exp Med. 2019 Jan 1;247(1):35-40.

16. Koziell A, Grundy R. Frasier and Denys-Drash syndromes: different disorders or part of a spectrum? Arch Dis Child. 1999;81:365-9.

17. Tasic V, Gucev Z, Polenakovic M. Steroid Resistant Nephrotic Syndrome-Genetic Consideration. Vol. 36, Prilozi (Makedonska akademija na naukite i umetnostite. Oddelenie za medicinski nauki). 2015. p. 5-12.

18. Hashimoto $H$, Zhang $X$, Zheng $Y$, Wilson GG, Cheng X. Denys-Drash syndrome associated WT1 glutamine 369 mutants have altered sequence-preferences and altered responses to epigenetic modifications. Nucleic Acids Res. 2016 Dec 1;44(21):10165-76.

19. Matsuoka D, Noda S, Kamiya M, Hidaka Y, Shimojo H, Yamada Y, et al. Immune-complex glomerulonephritis with a membranoproliferative pattern in Frasier syndrome: A case report and review of the literature. Vol. 21, BMC Nephrology. BioMed Central Ltd; 2020.

20. Lipsk BS, Lipsk BS, Ranchin B, latropoulos P, Gellermann J, Melk A, et al. Genotype-phenotype associations in WT1 glomerulopathy. Kidney Int [Internet]. 2014 May 1 [cited 2021 May 8];85(5):1169-78. Available from: https://pubmed.ncbi.nlm.nih.gov/24402088/

21. Trautmann A, Bodria M, Ozaltin F, Gheisari A, Melk A, Azocar M, et al. Spectrum of steroid-resistant and congenital nephrotic syndrome in children: The podoNet registry cohort. Clin J Am Soc Nephrol. 2015;10(4):592-600.

22. Park E, Lee C, Kim NKD, Ahn YH, Park YS, Lee JH, et al. Genetic Study in Korean Pediatric Patients with Steroid-Resistant Nephrotic Syndrome or Focal Segmental Glomerulosclerosis. J Clin Med [Internet]. 2020 Jun 26 [cited 2021 May 8];9(6):2013. Available from:

http://www.ncbi.nlm.nih.gov/pubmed/32604935 
23. Chan AOK, But WM, Lee CY, Lam YY, Ng KL, Loung PY, et al. Aetiological bases of 46,XY disorders of sex development in the Hong Kong Chinese population. Hong Kong Med J. 2015 Dec 1;21(6):499510.

24. Liu EK, Suson KD. Syndromic Wilms tumor: a review of predisposing conditions, surveillance and treatment. Transl Androl Urol [Internet]. 2020 Oct 1 [cited 2021 Apr 15];9(5):2370-81. Available from: http://www.ncbi.nlm.nih.gov/pubmed/33209710

\section{Figures}

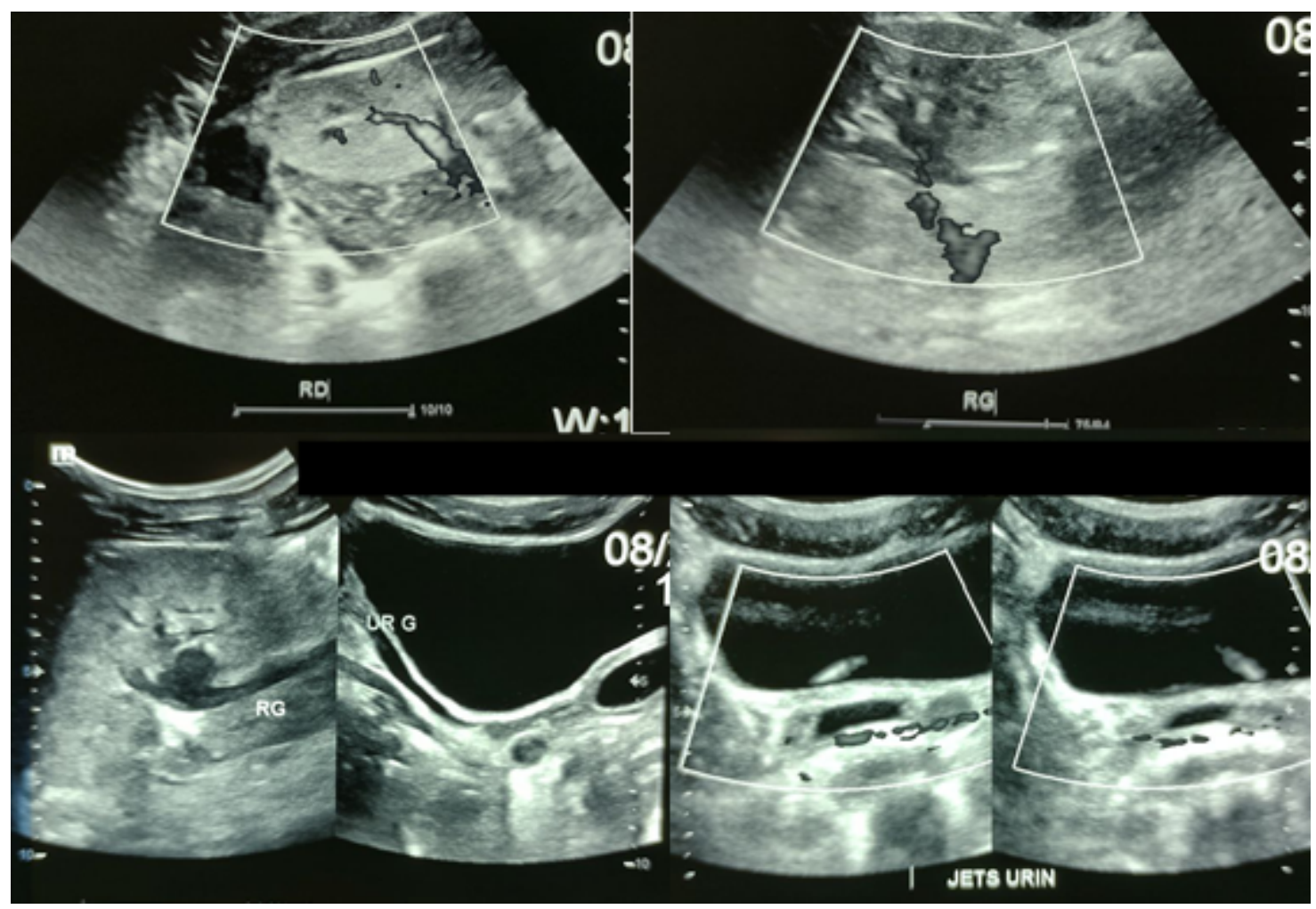

\section{Figure 1}

Ultrasound image of the kidneys 


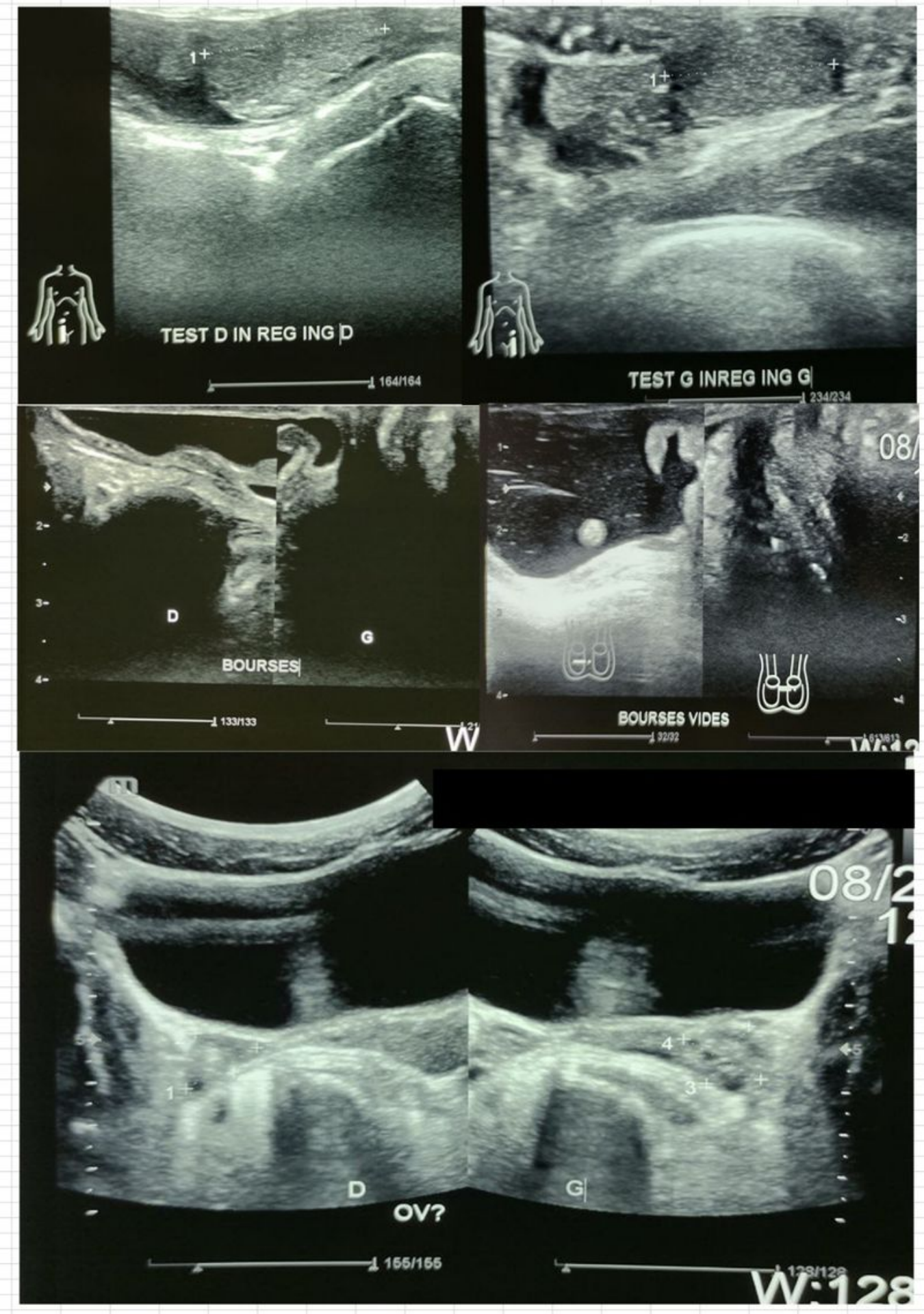

Figure 2

Identification of the testicles and ovaries on abdominal-pelvic ultrasound 


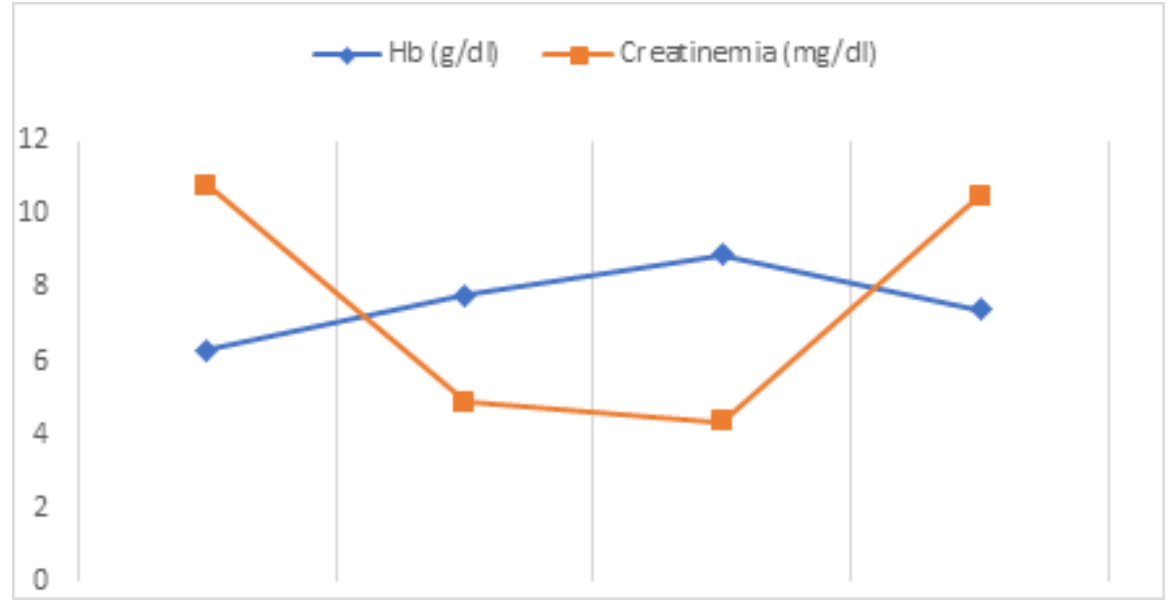

Figure 3

Curve of variation of hemoglobin and serum creatine during the last 3 months 